\title{
Fragmented participation in management of the fishery for small pelagic fish in South Africa - inclusion of small-rights holders is a complex matter
}

\author{
Mafaniso Hara, J. Rogerson, J. de Goede and Jesper Raakjær
}

\begin{abstract}
The reasons why most small-rights holders do not participate in management of the fishery for small pelagic fish ('small pelagics') in South Africa, despite legislation and policy encouraging their participation, were analysed. Membership of the Small Pelagics Management Working Group (SPMWG), the main participatory governance organ, is limited to representatives of recognised stakeholder associations. Rights holders therefore have to belong to a stakeholder association, which then selects a member or members to represent them on the SPMWG. Small quotas and the difficulties of sourcing capital mean that small-rights holders are not able to invest in infrastructure. Besides, most of the small-rights holders and their companies lack experience and management skills to survive independently in this highly competitive industry, which is based on high volume and low profit margins. As a result, most of the small-rights holders have no option but to enter into complex catching and processing agreements with vessel- and factory owners belonging to the existing recognised stakeholder associations. For the small-rights holders, it does not make sense to join these associations or even to form their own if they cannot actively participate in the industry independently. Greater participation by small-rights holders should start with their genuine integration into the industry through improved ability to invest in infrastructure and through management skills development. Most likely, this will require an interventionist approach by government.
\end{abstract}

\section{Introduction:}

South Africa's Constitution (RSA 1996, sections 40 and 41 in particular) provides the foundation for cooperative governance and enshrines the involvement of citizens in decisions over issues that affect them, such as the management of natural resources. This is further strengthened through Chapter 2 of the National Environmental Management Act (NEMA; RSA 1998a) - the overarching legislation for management of the environment in South Africa. NEMA is the first step in giving legal effect to the environmental rights in the Constitution through, among others, promotion of participation of stakeholders in environmental governance. Public participation in environmental management is therefore a legal requirement in South Africa. In this context, the Marine Living Resources Act (MLRA; RSA 1998b) gives legal and operational effect to the imperatives of the Constitution and of NEMA. 
Participatory management (co-management) refers to an institutional and organisational arrangement between government and user groups for effective management of a defined fishery (Jentoft 1989; Sen and Raakjær Nielsen 1996). The general functions of co-management have been identified as: the sharing of power and responsibility for management decision-making; the encouragement of partnerships; and provision of user incentives for sustainable use of resources (Wilson et al. 2003). Participatory management is a compromise between government concerns for sustainable utilisation and conservation (as the custodian of public resources) on the one hand, and users' demands for equal opportunities, self-determination and selfcontrol on the other. The approach makes two assumptions: that users must have a stake in management and, secondly, that partnership between government agencies and resource users is essential for positive management outcomes. Participatory management goes beyond mere consultation in that users not only have a direct role in decision-making but also have the authority to make and implement decisions in specified areas of responsibility (Jentoft and McCay 1995; Hersoug and Rånes 1997).

When organising for co-management, the issues that have to be addressed are similar to those in the theory of democracy and raise the classic questions of 'representation' and 'scale' (Mikalsen 1998; Gray 2005a). One of the greatest challenges is balancing these two problems of the democratic process. In the South African fishing industry, as in most other fishing industries, a common problem for the representation of user group interests is that, all too often, they reflect the internal divisions of a heterogeneous industry that traverses sectoral, size, geographic and historic racial lines. As a result of these divisions, capabilities and aspirations for deeper involvement in the co-management process may be limited. A prerequisite for successful co-management is its inclusiveness and a relatively simple organisational structure incorporating strong, widely respected and fully representative user-group organisations (Mikalsen 1998; Wilson et al. 2003; Gray 2005b). One of the most difficult aspects of co-management is deciding which stakeholders should be represented and how those representatives should be chosen. Symes (1997) points out that most so-called co-management systems are based on single-interest representation drawn from the harvesting sector. There is strong argument in most instances for co-management to be more inclusive and to include multiple interests in pursuit of a more broadly constructed agenda (Bavinck et al. 2005; Kooiman et al. 2005; Swyngedouw 2005), even though this presents the problem that representation could be expanded to unmanageable levels (Mikalsen et al. 1996). Hence there is need to decide how the institutional set-up can be as democratic and as inclusive as possible without sacrificing its efficiency. As a result, the last few years have seen a shift towards the concept of fisheries governance ${ }^{1}$ (Bavinck et al. 2005; Kooiman et al. 2005; Swyngedouw 2005; Symes 2006). Co-governance organisations cannot, therefore, afford to be too large; yet the alienation of particular stakeholder groups risks the erosion of co-governance's greatest benefit - the legitimacy of the system

\footnotetext{
1 'Governance is the whole body of public as well as private interactions taken to solve problems and create societal opportunities. It includes the formulation of principles guiding those interactions and the care for institutions that enable them' (Kooiman and Bavinck 2005, p 17)
} 
and its outputs (Mikalsen 1998; Bavinck et al. 2005; Kooiman et al. 2005). The issue of scale raises the question of the locus of user participation. The solution to this appears to be similar to democracy; that democracy works better in small settings (Michels 1915; Mikalsen et al. 1996). The larger the organisation, the more difficult it is to maintain a democratic process based on direct participation. With increasing scale, organisations tend to rely more on aggregation rather than integration in the decisionmaking process (Mikalsen et al. 1996; Symes 2006). With aggregation, the tendency is for members to become more focused on winning instead of trying to reach agreement on what position their organisation should take on management issues.

South African commercial fisheries have historical precedence in the form of the commercial industry working closely with the management authority (the former Sea Fisheries Authority), albeit as an exclusionary form of participatory management under apartheid (Hutton et al. unpublished data). ${ }^{2}$ With the promulgation of the MLRA following democracy in 1994, a great number of new rights holders (those that joined the industry post 1994) from the historically disadvantaged racial groups entered the fishing industry (Raakjær Nielsen and Hara 2006; Isaacs et al. 2007; Hara and Raakjær 2009). The policy for long-term rights (DEAT 2005a, 2005b) requires the establishment of working groups for management of commercial fisheries.

In the sector for small pelagic fish ('small pelagics'), the Scientific Working Group (SWG) and the Small Pelagics Management Working Group (SPMWG) are the formal governance structures for the sector where scientists, representatives of stakeholder groups and non-governmental organisations (NGOs) discuss scientific and management issues for recommendation to the Deputy Director General (DDG; head of the Branch: Fisheries Management, in the Department of Agriculture, Forestry and Fisheries [DAFF]) for final decision (DAFF 2010). Some of the key objectives of the SWG are to recommend total allowable catches (TACs) and total allowable bycatches (TABs) to the Chief Director: Marine Resource Management and for developing decision tools such as operational management procedures (OMPs). The SPMWG is the body for deliberations on management, development and operational issues in the sector. DAFF prefers that rights holders be represented by a selected member of a recognised stakeholder association (DAFF 2010). This is to try and prevent membership of the SPMWG growing to unmanageable numbers and to ensure effectiveness and efficiency of the working group, which is consistent with the co-management principles discussed above. Thus it is mainly rights holders who belong to a stakeholder association that will have their interests and views represented on the governance structures. At the time of writing there were three recognised stakeholder associations in the smallpelagics sector, namely South African Pelagic Fishing Industry Association (SAPFIA), the Eastern Cape Pelagic Association (ECPA) and the Weskus Pelagiese Vissers Vereniging (West Coast Pelagic Fishers' Association; WPVV). 3 The first two are rights-

\footnotetext{
${ }^{2}$ Hutton T, Raakjær Nielsen J, Mayekiso M. 1999. Government-industry co-management arrangements within the South African deep-sea hake fishery. Paper presented at the International Workshop on Fisheries Comanagement, Penang, Malaysia, 23-28 August 1999

${ }^{3}$ WPVV is defunct. A new labour union called the 'South African Pelagic Fishers Union' was registered to replace it, effected 1 April 2014
} 
holder associations while the last was an association for skippers and crew members based on the West Coast.

Stakeholder associations such as SAPFIA and ECPA are non-profit organisations formed to promote and protect the interests of their members. An association represents its members in negotiations with government or other organisations such as labour unions. The association secretariat communicates with its members on any new developments in the industry, changes in policy and legislation, and any other matters that are of interest to their members. There is an annual membership fee, used to run the organisation and its activities, which must be paid. In recent years SAPFIA has introduced a policy that allows a graduated membership fee rate based on size of the right. This is to encourage rights holders with small rights to join. SAPFIA argues that the interests of all members are handled equally, not on the basis of the size of the right and the related fee amount paid. Only members are invited to association meetings or receive communications on issues and decisions. Associations do not and cannot act on behalf of third parties such as rights holders with various agreements with their members.

From 2006 to 2012 an average of $44 \%$ of anchovy rights holders were members of SAPFIA, $2 \%$ were members of ECPA and $8 \%$ were members of both SAPFIA and ECPA (JdG, DAFF, unpublished data). 4 An average of $46 \%$ of the anchovy rights holders were not affiliated to either of the two associations (Figure 1). Of the sardine rights holders, an average of $13 \%$ were members of SAPFIA, $31 \%$ were members of ECPA and $8 \%$ were members of both associations. An average of $48 \%$ of the sardine rights holders were not affiliated to either of the two associations (Figure 1).

The concern is that the views and interests of nearly half of the rights holders, in that they are non-affiliated, are not officially represented on the SPMWG. Government is anxious that the non-affiliated group needs to be better integrated as part of transformation of the industry and as part of inclusive management decision-making within the fishing industry (DEAT 2005a).

Fragmentation in commons management is a global problem. The DARMA (Defragmenting Resource Management in Southern Africa) project, which this study was part of (see Acknowledgements), aimed to build networks and management approaches that can integrate resource management to enhance biodiversity of exploited commons while alleviating poverty at the same time. In this study, we aimed to try and understand why almost half of the rights holders are not actively participating in management of the small-pelagics fishery. A related question was whether the non-affiliated group can be brought into the fold so that their views and interests can be represented directly.

\footnotetext{
${ }^{4}$ The above statistics were calculated from actual paid-up members of the associations. The fishery performance review conducted in 2010 yielded very different statistics i.e. a perception survey indicated that 92 out of the 109 rights holders (84\%) were represented by an association and $73 \%$ of the 92 rights holders declared their confidence in these associations (DAFF 2012a)
} 


\section{Definition of 'small-rights holders' and 'economic viability'}

For this study, the Department of Trade and Industry (DTI) definition of a small business was applied when defining a small-rights holder. The DTI bases the definition of size of a business entity on its annual turnover. This varies among the various sectors (e.g. manufacturing, wholesale trade, commercial agents and allied services, finance and business services, community, social and personal services, etc.).5 Based on the National Small Business Amendment Act (RSA 2003), the minimum annual turnover for a small business entity was put between R6 million and R12 million. Another important aspect of the definition of size is the number of people employed which, in the case of a small business, is between 10 and 49 people.

For the period 2006 to 2012, the average landed value of raw sardine was R1 526 per tonne. ${ }^{6}$ If we applied the lowest annual turnover (R6 million) stipulated by the DTI and applied this to raw sardine landed value, this would mean that for 2012 (when the TAC for sardine was 100 ooo $t$ [DAFF 2012b]) a sardine-only rights holder would have required $3932 \mathrm{t}$ of sardine to achieve a turnover of R6 million (only the five biggest companies in the sector met this criterion).

Note that the DTI figures are 10 years out of date. It is likely that the minimum turnover figures must be higher by now, given annual inflation and a general increase in the cost of doing business.

The size of the right raises the issue of what a 'minimum economically viable right' might be. This is also related to the policy objective that rights holders are expected to invest in the industry to create employment and as a demonstration of long-term interest in remaining in the industry. Although this might vary annually depending on the size of the TAC, the majority of rights holders cannot even meet the criteria for being categorised as a 'small business'. Based on this definition, rights holders who have rights only in sardine without rights in anchovy are likely to face an even greater challenge.

\section{The small-pelagics fishing sector}

The small-pelagics fishery is a capital-intensive sector based on rights for sardine Sardinops sagax and anchovy Engraulus encrasicolus, with associated bycatches for round herring Etrumeus whiteheadii, Cape horse-mackerel Trachurus capensis, chub mackerel Scomber japonicus and meso-pelagic species which include lightfish Maurolicus walvisensis and lanternfish Lampanyctodes hectoris. The sector is the largest in terms of landed volume and second only to hake (Merluccius spp.) with regard to landed value (George Warman Publications 2013). Most of the sardine is canned while a small proportion is packed for bait. The anchovy is reduced to fishmeal, fish oil

\footnotetext{
5 The lack of fishery-sector-specific operational definitions calls for socio-economic studies to define what an economically viable right could be in each fishing sector, in order to assist with decisions about minimum viable quotas

${ }^{6}$ The average landed value for raw sardine was calculated using information obtained from factories by JdG for the years 2006 to 2012. The value of anchovy used to be based on the fishmeal price. The Fishmeal Association does not give recommendations on this price any more because of competition laws and past cases around price fixing (Hara 2013). Factories and rights holders therefore negotiate the prices individually. For this reason it was not possible to obtain an average price for landed anchovy
} 
and fish paste. In 2012, there were six canneries, six fishmeal plants and about 15 packing entities officially registered as operational and active (JdG, DAFF, unpublished data). In 2005, the government of South Africa issued 15-year (2006 to 2020) longterm fishing rights for the sector (DEAT 2005b). At the start of the 2006 fishing season, 115 entities had been awarded long-term rights in small pelagic fish (75 for both sardine and anchovy and 40 for sardine only). By 2012 the number of rights holders had reduced to 109 (71 held both anchovy and sardine rights and 38 held sardine-only rights), mainly due to consolidation and rights transfers. The number of approved vessels, based on applications received during the 2006 rights allocation process, was about 100. This figure was set as the industry limit (DEAT 2005b). The number of vessels that were effectively operational had declined to 74 by 2012.7 The sector is managed using OMPs, which recommend annual TACs for anchovy and sardine and TABs for the associated bycatch species (Fairweather et al 2006; Butterworth 2007).

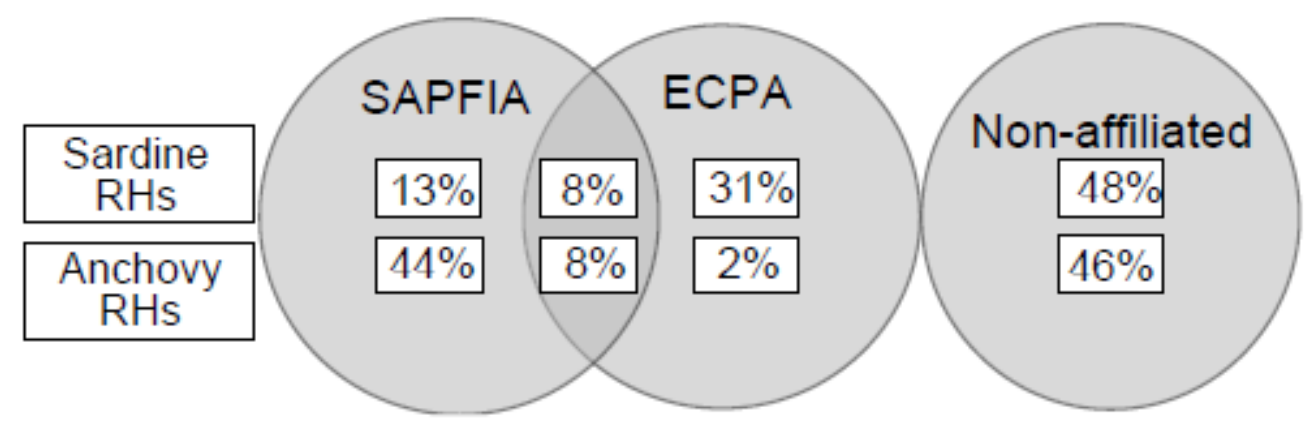

Figure 1: Average proportion of rights holders (RHs) who were members of SAPFIA, ECPA or were non-affiliated (2006-2012)

In 2002, South Africa committed to the implementation of an ecosystems approach to fisheries (EAF) (Shannon et al. 2004, 2010; DEAT 2005a, 2005b; Petersen et al. 2010). The small-pelagics sector is one of the fisheries in which an EAF is being implemented (Paterson et al. 2010; Paterson and Petersen 2010). The requirement for active and meaningful stakeholder participation in management is part of one of EAF's three top objectives - 'Ability to achieve' (FAO 2003; Paterson et al. 2010; Petersen et al. 2010). This was supposed to be enhanced through implementation of long-term rights (Hara 2013).

\section{Methods}

A number of approaches were used to collect the data and information for the study. These approaches were: unstructured interviews, meetings and a workshop; analysis of landings; and ethnographs of small-rights holders. These are outlined below.

\section{Interviews and meetings}

Eight small-rights holders that are not affiliated to any of the stakeholder associations and three rights holders that are members of SAPFIA were interviewed. A workshop

\footnotetext{
${ }^{7}$ Various reasons, including increased fuel cost, reduced factory capacity, fi sh availability, vessel age, the NEMA: Air Quality Act (RSA 2004), etc. led to this reduction in vessel usage (JdG, DAFF, unpublished data)
} 
attended by 12 people (comprising rights holders from both the Western Cape and the Eastern Cape) was held in 2012. Five key informants working for companies that are members of SAPFIA (three) and ECPA (two) were interviewed. Interviews were also conducted with the Secretary General of SAPFIA and the chairman of ECPA, three managers for large companies that are rights holders and also vessel- and factory owners on the West Coast and in Cape Town. Four vessel owners that do not have rights but catch fish on behalf of rights holders, and the Chairman and Secretary of the former WPVV and officials from Branch: Fisheries Management, DAFF, responsible for managing the small-pelagics sector, were also interviewed.

One of the authors (JdG) is a fisheries manager working in the day-to-day operational management of the small- pelagics sector. Two of the authors (MMH and JR) attended the 'Performance Review' workshops (DAFF 2012a) on long-term rights in the sector that were held on the 25th (West Coast) and 26th (Cape Town) of June 2012, at which the results of the reviews of the performance of rights holders since 2006 against the set objectives for each sector were discussed between DAFF and stakeholders.

\section{Analysis of landings}

Following the workshops, meetings and interviews, it was realised that one of the key reasons why so many small- rights holders remained outside the stakeholder associations was related to operational dynamics of the industry, especially the catching and processing agreements. It is important, therefore, to understand how these work. Hence an analysis was conducted of official DAFF data on the size of the catch, the vessels responsible for catching the TAC for the 2012 season, and where the catch was landed. These data were analysed in terms of:

number of vessels that had been registered as operational for the season and the spread in ownership of these vessels;

number of vessels that delivered fish at the seven largest canning and fishmeal factories; the proportion of the sectoral TAC that had been landed at each of those seven processing factories;

the proportions of the TAC landed at the seven factories that had been caught by vessels that belonged or did not belong to the factories; and

the proportions of the 2012 TAC held by (i) SAPFIA members, (ii) ECPA members or (iii) non-affiliated rights holders.

\section{A note on data accessibility}

Difficulties with databases were experienced at two levels. The first was that contact details for rights holders captured on DAFF's Marine Administration System (MAST) were outdated. Although DAFF requires parties to notify the Department of any changes to contact details, this is not done in most instances. This, in turn, leads to third parties receiving invalid contact details when these are sourced via the Public Access to Information Act (PAIA; RSA 2000). ${ }^{8}$ For our research, rights holders whose details from MAST were invalid had to be found through word-of-mouth. Secondly,

\footnotetext{
${ }^{8}$ This, sometimes, gives the perception that invalid data are being provided deliberately by the Department, yet in reality DAFF can only provide information that is available and updated by rights holders
} 
PAIA legislation requires DAFF to release information using a prescribed process, because the information is presumed to be private under the PAIA law. Permission to access specific types of information - such as catches, processing agreements, etc. - for an individual rights holder for inter alia research purposes, requires a PAIA application and prior approval by the DDG of the Branch: Fisheries Management. Having been granted access, it was found that the data were not always available in the required format, rendering interpretation difficult. In both contexts our efforts were facilitated by JdG, a DAFF Fisheries Manager, but our experience highlighted challenges associated with public access to fisheries information. Additionally, there is no guarantee that access will be granted because the final decision rests with the DDG.

\section{Results}

\section{Proportion of small-rights holders}

The cut-off limit of $3932 \mathrm{t}$ (or $3.932 \%$ of the 2012 sardine TAC) was used to analyse the proportion of rights holders who would have been classified as small-rights holders based on the 2012 sardine TAC. Only five of the 109 rights holders (i.e. 5\%) that were allocated sardine rights had equivalent to or more than this amount (Figure 2). Of the 109 rights holders, 38 (35\%) received sardine-only rights while 71 (65\%) received a combination of sardine rights and anchovy rights. 9

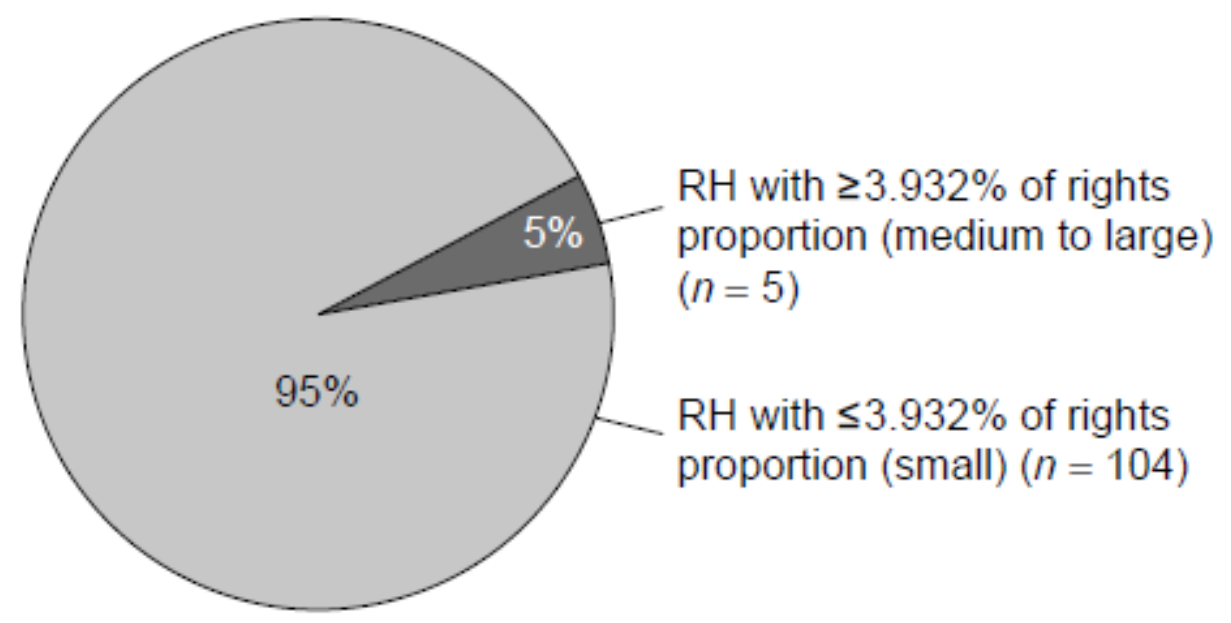

Figure 2: Proportion of small-rights holders and medium- to large-rights holders

\footnotetext{
${ }^{9}$ Applicants had to decide on their directed fishing rights requirements during the 2006 long-term rights allocation process, i.e. the sardine:anchovy preferred ratios. Once awarded, these may not change until 2020 (the next round of allocations). Sardine-only rights holders opted not to venture into an anchovy-directed fishery at the time of allocations
} 
Table 1: Companies owning more than one vessel of those registered as operational for 2012

\begin{tabular}{lc}
\hline Company & Number of vessels \\
\hline Eigelaars Bote (Edms) Bpk & 4 \\
Foodcorp (Pty) Ltd & 3 \\
HDC Familie Trust & 2 \\
Komicx Products (Pty) Ltd & 2 \\
Noordbaai Vissers Beperk & 2 \\
Oceana Brands Limited & 10 \\
Pioneer Fishing (West Coast) Limited & 3 \\
Premier Fishing SA (Pty) Ltd & 2 \\
Saldanha Bay Canning Company (Pty) Ltd & 3 \\
Sceptre Fishing (Pty) Ltd & 2 \\
Terrasan Pelagic Fishery (Pty) Ltd & 2 \\
West Point Fishing Corporation (Pty) Ltd & 4 \\
\hline Total & 39 \\
\hline
\end{tabular}

Table 2: Number of different vessels that delivered catch to the seven largest factories in 2012

\begin{tabular}{lc}
\hline Factory & $\begin{array}{c}\text { Number of different } \\
\text { vessels that delivered } \\
\text { catch during the } \\
\text { normal season } \\
\text { (January-August 2012) }\end{array}$ \\
\hline Afro Fishing (Pty) Ltd & 7 \\
Gansbaai Marine (Edms) Bpk & 16 \\
Marine Products Laaiplek & 17 \\
Oceana Brands (Hout Bay) & 22 \\
Oceana Brands (St Helena Bay) & 21 \\
Oranjevis & 17 \\
West Point Processors (Pty) Ltd & 27 \\
\hline
\end{tabular}

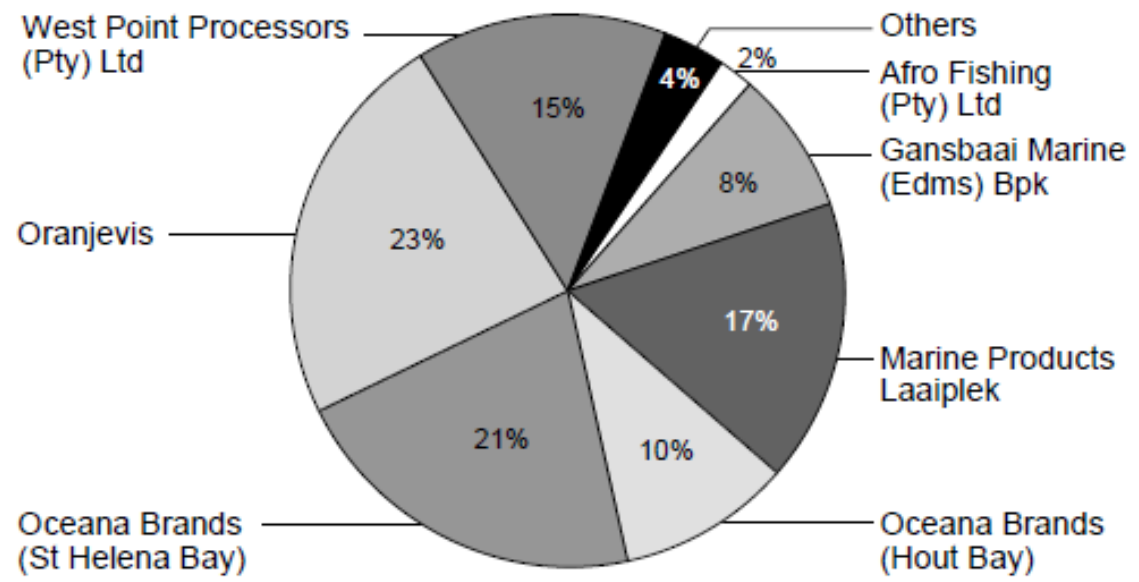

Figure 3: Distribution of small-pelagics catch (487 391 t) delivered to fish-processing factories in 2012 


\section{Vessel ownership}

A total of 74 vessels fished during the 2012 season (DAFF 2012a). These were owned by 47 different vessel owners. Thus of the 109 rights holders in 2012, 62 (57\%) did not register as vessel owners. Thirty-nine (53\%) of the 74 vessels were owned by 12 companies that owned two or more vessels each, with Oceana owning the highest number (Table 1), whereas the other 35 (47\%) vessels were owned by single-vessel owners.

\section{Catch processing}

Vessels are permitted to offload catch at various factories (provided these are reflected on the permits), which is encouraged by DAFF for various reasons as explained below. Table 2 shows the number of vessels that delivered catch to each of the seven largest canning and fishmeal factories during the 2012 season. The total small-pelagics catch for 2012 was $487391 \mathrm{t}$. This included the TAC for sardine and anchovy as well as all associated bycatches. Of this, $469673 \mathrm{t}$ (96\%) was delivered to the seven largest factories (Figure 3).

\section{Interest group rights holdings}

Of the 2012 TAC for small pelagic fish, 68\% was held by members of SAPFIA, 8\% by members of ECPA and $24 \%$ by non-affiliated rights holders (Figure 4 ).

\section{Perspectives and insights from stakeholder interviews, workshop and meetings}

Small-rights holders indicated during interviews that one of the biggest problems they face is that the size of their rights is too small for them to invest in their own vessels as individual rights holders. This then requires trying to form consortia to buy a vessel as a group or buying shares in existing vessels. Some had gone the first route with success but others with disaster. For example, a number of small-rights holders had combined to buy an old vessel that was affordable. They were obliged to use their own resources because they had been unable to secure a bank loan. Banks apparently argue that they do not view a fishing right as surety. The operational costs of running an old vessel proved too high, to the extent that they had to abandon its use. The consortium broke up as a result. Another group of small-rights holders said they had a vessel and were using it to catch their rights. Apart from catching their own rights, they also caught fish for other rights holders that did not have vessels. This was the only way that the vessel could be kept profitable. A woman that had been in the industry since the medium-term rights allocation of 2002 said that she had inherited the business from her deceased father. She had been working in the company with her father for some time before he died and as such she had a sound knowledge of the industry. 


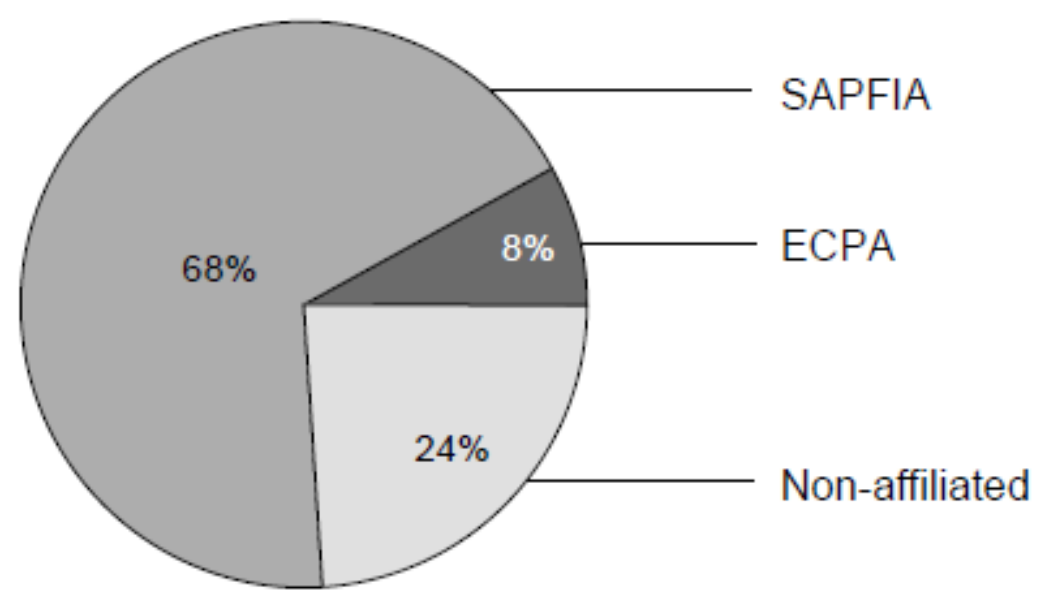

\section{Figure 4: Distribution of the TAC for the small-pelagics sector held by SAPFIA members, ECPA members and non-affiliated rights holders for the 2012 season}

Her company had its own vessel. Apart from rights in sardine, she also had rights in hake and linefish. This portfolio of rights enabled her to run a successful fishing business. She said that she helped other small-rights holders through catching agreements. She was a member of SAPFIA. Another individual rights holder with a vessel also had another rights portfolio and ran a bait-packing factory in Mitchells Plain, Cape Town. He also said that it was very helpful to have other rights, such as linefish, apart from sardine rights, and that having his own factory made it possible to add value to both his sardine and linefish rights. He said that he was not a member of any association. He seemed to regard his membership of a particular political party as being more important.

Most small-rights holders did not have their own vessels or shares in vessels and were obliged to enter into catching and processing agreements with vessel owners and factory owners. The way the catching sector is organised means that once one has a catching and processing agreement, one's involvement in one's own right becomes minimal, because it is the skipper and his crew who go to sea and then deliver the catch to the factory that one has a processing agreement with. One is then informed by the factory about how much catch was delivered on one's quota and how much one is owed by the factory after costs have been deducted. Some elect to sell their annual quota to vessel owners or factories, thereby receiving payment upfront and having no further direct involvement. Given such operational dynamics, most rights holders without vessels did not see any purpose in being members of associations or in forming their own. Some claimed that they receive all relevant information from their partners in the catching and processing agreements, thus negating the necessity for membership.

The fact that there are so many rights holders without vessels (57\% in 2012) means that there exists a business opportunity for vessel owners without rights to catch fish on behalf of rights holders. Thus, apart from factories, there exist vessel owners whose only business is to catch fish for those without vessels. A number of skippers and/or 
former rights holders who own vessels but lost their rights had entered this kind of business.

As manager of the sector and convener of the SPMWG, DAFF would like all rights holders to be represented on the working group, which is the primary formal platform for expressing views and providing inputs into management. This would ensure that stakeholder interests are heard and protected. DAFF sees the working group as an important means for rights holders to keep up to date with developments in the sector and also for discussing policy and legislative and operational issues. The working group, however, cannot accommodate all 109 rights holders at its meetings. The general terms of reference (ToR) for management working groups (MWGs) (DAFF 2010, p 2) state that an 'MWG shall have no more than ten members who are representatives of recognised industrial bodies. The limited size of the MWG is to ensure that the MWG is effective and efficient.' Hence rights holders are advised that official representation on the working group can be through industry stakeholder associations only. Nevertheless, the ToR state that the chair of the working group may use his or her discretion to allow or invite rights holders who are not members of an association, or other stakeholders, to attend working group meetings as observers.

\section{Three mini portraits (ethnographs) of small-rights holders}

In the following accounts, three rights holders gave personal accounts of how they entered the industry and the challenges of being a small-rights holder that they have encountered. These anecdotes provide insights into some of the issues and difficulties faced by this group of rights holders. The MLRA created a situation whereby, for the majority of rights holders, quotas were allocated in small proportions of the TAC, in order to apportion the resource more widely as part of transformation. For smallrights holders, finding a way of making use of their rights is the ideal and desired outcome, although usually not very easy.

\section{Craig - trying to become established and survive}

Craig1010 started working in the fishing industry at an early age because his father had fished for a living. He inherited the family business. When rights were allocated in 2006, Craig received a sardine quota but it was difficult to run a viable fishing business. This was for two main reasons: difficulties of obtaining capital for a vessel; and the small quota he received (0.38\% of sardine TAC). He had explored ways of working together with other small-rights holders in a similar situation, yet it was still not possible to source capital for a vessel, even as a group. Ultimately he, together with other rights holders, had to resort to entering into catching agreements with vessel owners in order to increase the amount of fish caught. Craig observed that the largest proportion of the quota in the sector was held by large companies and, as a result, selling small amounts of fish to bait packing and canning companies was always in competition with the large fishing companies. Craig was trying to use his quota himself, in preference to selling it to a company, although this was difficult. Craig felt that the stakeholder associations represented the concerns of the large companies whereas the difficulties faced by small- rights holders/companies, such as access to

\footnotetext{
${ }^{10}$ Real names have been changed
} 
capital, were excluded from the agendas of these associations. Hence he chose not to join any of the associations.

\section{Nico - selling one's quota}

Like Craig, Nico had little formal education and entered the fishing industry through his father. Prior to promulgation of the MLRA (1998b), fishing seemed a relatively lucrative enterprise, because one had enough quota to be comfortable, if not well off. With the advent of long-term rights under the MLRA, Nico was allocated a right (0.45\% of sardine TAC) which was not enough to invest in his own vessel and fish on his own profitably. The reason for this was that each sea trip required fuel, a skipper and crew. One had to offset these costs through one's quota. Since Nico's quota did not allow for this, it was easier for him to sell his quota rather than use it personally. Large fishing companies are usually happy to buy quota from small-rights holders due to inter alia TAC reductions. The net effect of selling a right effectively made Craig a 'paper-quota holder', which is against DAFF's policies.

\section{Peter - issuing of rights to non-fishers}

Peter and his colleagues knew of someone who applied for rights despite having never fished. This man qualified through being a 'historically disadvantaged individual' (HDI), as defined in the MLRA, and, as a result, was granted a right (0.76\% of sardine and $0.26 \%$ of anchovy TAC). This is because, when the MLRA was promulgated, it set out to redress past inequalities. At first, Peter was happy for him and assumed that the man would learn how to fish and become personally involved in the industry. Instead, the man bought a vessel and employed a skipper (and crew) to work for him. He also bought quota from fishers who did not have their own vessels. Peter was unhappy about this because this man was profiting from fishing without having any history in fishing, nor any intention of becoming a 'proper sea-going fisher'. For this man, fishing was a purely business enterprise, which contrasted with people like Peter, for whom fishing was not only employment, but also a vocation. Peter regretted that he did not report to DAFF, during the rights allocations process, applicants such as this person, who had no historical interest in fishing and whose only interest was to profit from fishing without any desire to commit to the industry. As a result of the categorisation of potential rights holders as HDIs, several cases like this one emerged, which resulted in fishers like Peter, who had fished their whole lives, receiving reduced quota. Peter had a catching and processing agreement with a fishing company, since the small quota made it impossible to invest in his own vessel. Peter regarded belonging to an association as unnecessary because he did not actually fish and, like most fishers, he felt that he was represented by companies that he had a catching and processing agreement with.

\section{Discussion}

\section{Catching and processing webs and networks}

When applying for renewal of their annual fishing permit, ${ }^{11} 11$ rights holders are required to state, firstly, which vessels they will use to catch their quota and, secondly, to which factories they will deliver their catch. Rights holders are encouraged by

\footnotetext{
${ }^{11}$ Within long-term rights, rights holders have to renew their fishing permits annually in accordance with the MLRA
} 
DAFF to list as many vessels as possible that they would use and as many factories as possible to which they would deliver their catch. This is to give rights holders broad options and flexibility. Also, because fish are not always caught close to the factory where rights holders usually deliver, this flexibility allows fuel savings, quicker turnaround time and other practical economic benefits. Additionally, in the event of vessel breakdown, it is desirable to land and offload at the nearest factory. The permit conditions do not require that the rights holders state the terms of the catching and/or processing agreements that they enter into. ${ }^{12}$

The majority of rights holders (57\%) were not registered as vessel owners in 2012 (some stated that they have shares in some vessels that they use), necessitating having catching agreements with vessel owners. The sardine TAC declined from 204 ooo $t$ in 2006 to $162436 \mathrm{t}$ in 2007 and then to as low as 90 ooo $t$ annually for the years 2008 to 2011 (JdG, DAFF, unpublished data). The downturn in biomass of sardine in recent years and the general variability in geographic availability (Hutchings et al. 2009; van der Lingen et al. 2011) meant that most rights holders did not have viable ${ }^{13}$ quotas that would allow them confidence to invest in their own vessels. Few rights holders have their own factories, and hence most have to have processing agreements. Of the $96 \%$ of the 2012 TAC that was delivered to seven factories, only $24 \%$ was caught by factory-owned vessels, the other $76 \%$ being caught by non-factory-owned vessels through catching and processing agreements.

Figure 5 shows the complex web of possible catching and delivery agreements that exist in the sector among the various types and categories of rights holders and stakeholders. Rights holders who do not have vessels enter into catching agreements with factories that have vessels, rights holders that have vessels or vessel owners who do not have rights (linkage (1)). Thus rights holders can use more than one vessel to catch their quota over the course of the season. The vessels deliver catch to various factories depending on whose catch it is. Given that rights holders will have processing agreements with more than one factory, they can instruct the contracted vessel to deliver their quota to various factories over the duration of the season (2)). Vessels may also be catching fish for more than one rights holder at a time, so that they may deliver specific amounts to specific factories from one catch (2) in some cases, vessel-owning factories also contract additional external vessels to catch the fish for them (3)). For example, the seven factories named in Figure 3 used contracted vessels to catch and deliver their fish apart from using their own vessels (Table 2).

\footnotetext{
${ }^{12}$ The permit conditions also do not require that the rights holders state the length of the agreements, although such agreements must be valid for the current season. Rights holders themselves choose and determine the agreement period. Some look for and/or negotiate better agreements from year to year

${ }^{13}$ While there is need for definition of an agreed formula for calculating what a 'minimum economically viable quota' (and the combination of sardine and anchovy therein) in the industry might be (collecting accounting data for rights holders did not form part of this study, neither are such data readily available), most small-rights holders had been allocated less than $0.4 \%$ of the sardine TAC and/or less than $0.4 \%$ of the anchovy TAC (George Warman Publications 2007). Thus the value of the quota of most rights holders was well below DTI's 2003 defi nition of a small business (with turnover of R6 million-R12 million annually) (RSA 2003). Indeed, most small-rights holders stated that their allocated rights provided little opportunity to make investments in catching and/or processing equipment as individuals, given the cost-earning structure (high volume/low margins) in the small-pelagics sector
} 


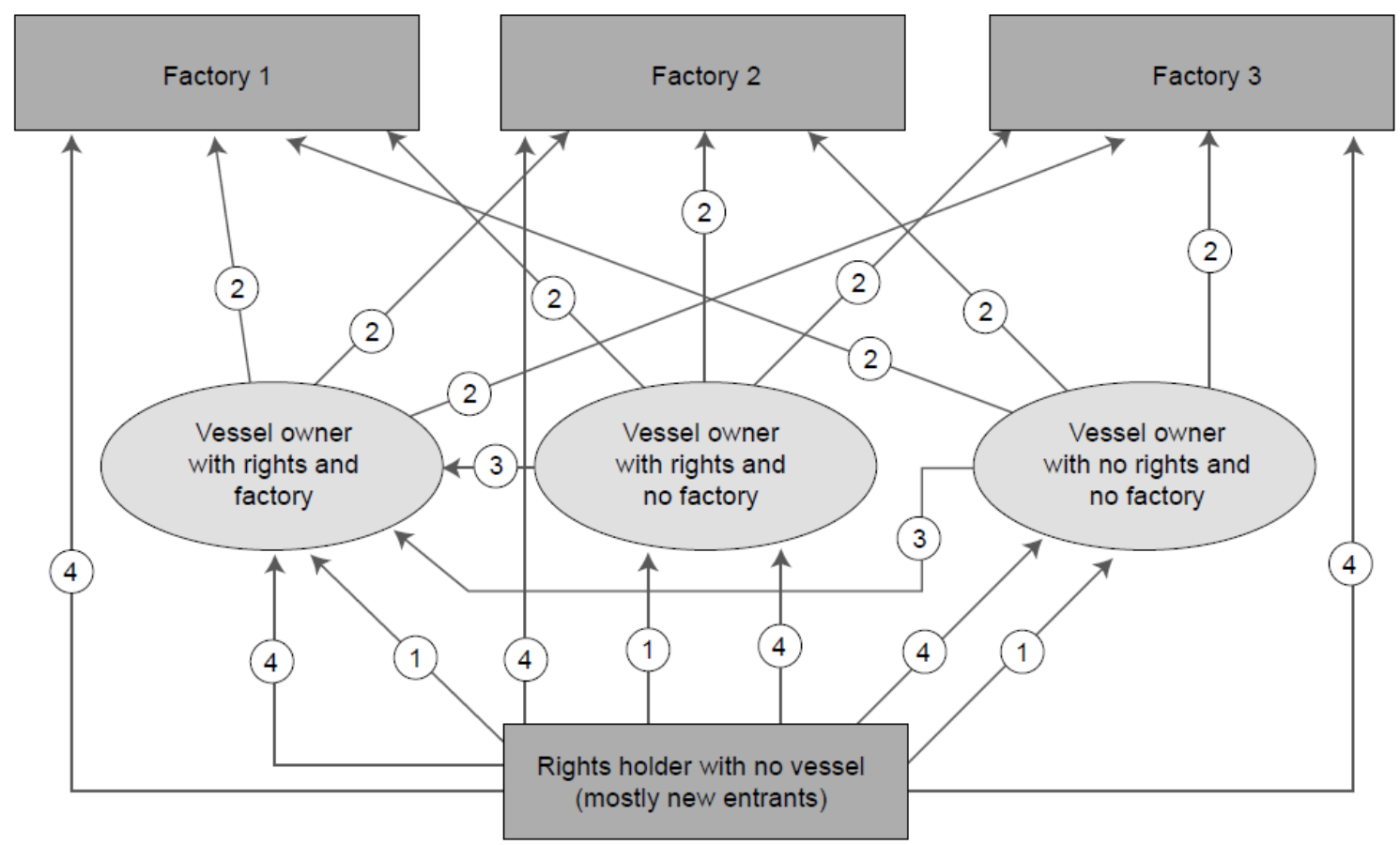

Figure 5: Possible catching and processing agreements among the various stakeholders in the small-pelagics industry. Explanation of linkages is provided in the text

In other instances, rights holders lease ${ }^{14}$ their annual quota or a proportion of it to factories or vessel owners (4)). In the case that quota is leased to vessel owners, these will have processing agreements with various factories. Given that vessel owners can have their own processing agreements with factories, these could also be used by the rights holders without vessels, indirectly making the network of factories where one's quota can be delivered for processing even more extensive. Factories use either their own vessels (2) to catch their quota (or quota that they have leased from other rights holders) or contract out the catching (3) to other vessels. Among the big factories on the West Coast, it is normal to take delivery of each other's catch (2)). Thus the records show, for example, that Oceana's vessels land fish at Oranjevis or West Point, and vice versa. The sharing of catch among the factories allows them flexibility in case of: bad weather preventing vessels from landing at a particular factory; a factory already running at full capacity; factory breakdowns; or labour disputes. Therefore this complex web of agreements allows and enables flexibility among the parties. ${ }^{15}$

\section{Is it necessary to belong to an industry stakeholder association?}

Given the catching and processing arrangements that rights holders without vessels, who are also mostly small-quota holders, have to enter into, is it necessary for them to belong to a stakeholder association so that their interests and views are represented?

\footnotetext{
${ }^{14}$ When a rights holder leases out their quota it becomes difficult for them to manage the catch

${ }^{15}$ Regardless of the web of agreements, it remains the responsibility of each rights holder to ensure proper and accurate management of their quota in accordance with DAFF's policy and legislation
} 
In the past, high membership fees had been stated by some small-rights holders as the reason for not applying for membership of SAPFIA. According to the Secretary General of SAPFIA, membership fees were subsequently restructured into graduated fee amounts based on the size of the right. This was done to encourage small-rights holders to join the Association. Some small-rights holders stated that they preferred to stay out of SAPFIA because it was dominated by large-rights holders with pre-1994 historical rights (Hara and Raakjær 2009; Nyikahadzoi et al. 2010; this study). Belonging to SAPFIA would therefore subsume their voices and interests. The formation of the national small, medium and micro-sized enterprises (SMMEs) Fishing Forum (George Warman Publications 2013) was based on this thinking (Hara and Raakjær 2009). The ECPA and the former WPVV are examples of two geographically based smaller organisations that represent the interests of their members independently of SAPFIA. Both have membership on the SPMWG. In some instances, rights holders believed that belonging to an industry-stakeholder association would strengthen their chances of obtaining and retaining a right/ quota, whereas some believed that remaining outside such organisations, especially if one was from a historically disadvantaged group, would politically strengthen one's case for obtaining and retaining a right (Hara and Raakjær 2009).

The need for admitting into the industry more rights holders from historically marginalised groups, as part of transformation, resulted in the fragmentation of quota into many small proportions, with the majority of rights holders obtaining less that 0.4\% of sardine and/or anchovy TAC (see George Warman Publications 2007). Most of these small proportions are not economically viable on their own, especially in a sector based on 'high volume/low margin' (Hara and Raakjær 2009). The proportions are even more uneconomical in seasons when the TAC is low, as has been the case for sardine, the species in which all quota holders have had rights since 2006. It is difficult, therefore, for small-rights holders to invest in their own infrastructure. This leaves them little choice other than to enter into catching and processing agreements, thereby characterising them as 'paper-quota holders'. The majority of rights holders that have not taken up membership in the existing industry-stakeholder associations are those that do not have their own vessels. Most state that they obtain information from their partners in the catch and delivery agreements. They argue that it is not necessary, therefore, to belong to a stakeholder association. Most of their partners belong to SAPFIA, which is the strongest industry-stakeholder association and whose members held nearly 70\% of the volume of rights in 2012 (Figure 4). According to this argument, their interests are thus already being (indirectly) taken care of by the strongest player in the industry. In other words the transaction costs of being a member of a stakeholder association are not justified if one is participating in the industry only indirectly through catching and processing agreements. For this reason, most small-rights holders do not see any reason for forming their own groups. The problem, however, is that the small-rights holders do not have the same interests and concerns as their agreement partners - the vessel owners and factory owners. Rights holders would presumably like to retain their rights in the industry in the next round, while factory owners would like to retain their current strong position in the industry. In fact, one of the conditions for renewal of one's rights after the current round of long-term rights expires in 2020 is demonstration of investment and active 
participation in the industry (DEAT 2005a), which means that the small-rights holders relying on catching and processing agreements will have to show active interest in their rights if they are not to lose them. ${ }^{16}$ At the same time, stakeholder associations such as SAPFIA are concerned largely with looking after, promoting and protecting their member's interests (George Warman Publications 2013). It is inaccurate to presume that, by extension, the existing stakeholder associations are also interested in ensuring the interests and concerns of non-members simply because they have catching and delivery agreements with their members.

Although DAFF would ideally like all rights holders to be represented on the industry management structures (S Pheeha, DAFF, pers. comm.) as a means of enhancing inclusive governance of the industry and defragmentation of management, South Africa's constitution gives citizens the 'right of association' and, similarly, their right not to belong to associations. Thus, the rights holders cannot be forced to form or belong to an association in order to qualify for representation on the governing structures. The political dynamic is that, as long as their rights and economic interests under current arrangements are not threatened, most of the currently non-affiliated rights holders have little or no incentive to join the existing stakeholder associations or to form new independent associations of their own.

\section{Conclusions}

Stakeholder participation is considered an integral component of changing ownership in fisheries (and of EAF) in the post-apartheid transformation of access rights to natural resources in South Africa, as well as of general fisheries policy for inclusive and democratic governance of the industry. From the preceding analysis and discussion, it is apparent that certain mismatches exist between government's request for rights holders to belong to a stakeholder association, the interests of large, established rights holders and the challenges and concerns of small-rights holders. DAFF's interest is that those involved in the industry should belong to a stakeholder association so that they can participate directly in decision-making, stay updated on day-to-day operational matters, research findings and development of the sector, and take part in addressing long-term sustainability issues. By not actively participating in management through direct representation, such rights holders do not ensure that majority considerations and inputs are being used in decision-making. Although the reasons for not taking up membership of rights-holder associations could actually be those given during interviews, non-participation could also be indicative of misunderstanding or misinformation about the objectives of the SPMWG and other processes that have been put in place to improve management of the sector. Whatever the genuine reasons, it is imperative that DAFF makes an effort to understand them in order to improve inclusive management of the sector.

Transforming the sector is a rather complex matter. It is important to remember that the small-pelagics industry operates on a high volume/low margin basis (Hara and Raakjær 2009). The sector is highly capital-intensive and only a few companies

\footnotetext{
${ }^{16}$ DAFF is likely to try to eliminate the holding of 'paper quotas' in the next round of rights allocation
} 
dominate the entire value chain from catching to marketing. Furthermore, the sector has to cope with periodic fluctuations in the annual TAC. ${ }^{17}$ This combination of factors has created an economic and operational environment which makes it difficult for small-rights holders to become established as independent entities, thereby indirectly driving a sizeable proportion of them to become paper-quota holders. As visualised in Figure 5, there exists a complex web of catching and processing agreements within the sector. This web has been part of the history of the fishery and Raakjær Nielsen and Hara (2006) questioned whether genuine redistribution of rights had really taken place when the state introduced long-term rights in 2006.

Rights-holder participation in management needs to be seen in the light of how the sector is operating de facto. It is evident that SAPFIA members directly or indirectly (through catching and processing agreements) control more than 90\% of the landings in the sector. SAPFIA and the ECPA are represented and are actively participating in management through representation on the SPMWG. On the one hand, it can be argued that networks and associations exist that allow for stakeholder participation. On the other hand, the situation in the sector seems to be a status quo of what has been happening during the last decade and, in effect, transformation has not led to increased active participation in the industry for most small-rights holders. A question to ask is whether government is enforcing transformation adequately, given the continued prevalence of paper-quota holders.

As indicated in the three mini portraits and interviews, small-rights holders choose not to participate because the catching and processing agreements enable both parties to an agreement to work 'around the system', or quotas are sold outright to vessel owners and/or factories. In this context, small-rights holders who engaged in these catching and processing agreements consider that they have no reason to join a stakeholder association.

Small-rights holders have generally been unable to establish economically viable enterprises because, in addition to individual quotas being too small, they have been lacking management skills and access to capital and because the industry operates in a global and highly competitive market (Isaacs et al. 2007; Hara and Raakjær 2009). Isaacs et al. (2007) made the observation that the state will have to play a more interventionist role by supporting small, emerging enterprises in order to ensure effective transformation. The state needs to establish institutional structures, both for the provision of credit facilities and to actively support skills development, if its aims to redistribute economic property rights and transform the ownership of this and other industries are to take lasting effect.

\footnotetext{
${ }^{17}$ The operational management procedure for the sector has a built-in mechanism that prevents TACs from being reduced by more than $20 \%$ (sardine) and 25\% (anchovy) annually (de Moor and Butterworth 2008) when the resource is abundant. This is in order to promote industry stability by protecting rights holders from large interannual variability in catch and thus disastrous business conditions. Even then, resource preservation at low biomass necessitates a larger reduction in TACs, resulting in appreciable changes such as from the high TACs of sardine of over $400000 \mathrm{t}$ in the early millennium to the current TACs of between 90000 and $100000 \mathrm{t}$
} 
According to Hara and Raakjær (2009), the government has argued that, while it was important to transform the industry and broaden participation for the historically disadvantaged, the proliferation of rights holders might not necessarily translate into effective participation. It might, therefore, be necessary to allow consolidation in some sectors in order to improve effective participation (DEAT 2007). ${ }^{18}$ One can argue that this is exactly what is happening in the small-pelagics sector. Most smallrights holders are being indirectly represented by SAFPIA or ECPA through being represented by the company with whom they have a catching and/or processing agreement.

Despite the foregoing, the authors are sympathetic to including small-rights holders in management. Our findings clearly show that most small-rights holders feel that they have little to gain from participating in management due to the structure of the industry. It is important, therefore, to focus on how to ensure genuine participation by small-rights holders in a fully transformed fishery. We believe that small-rights holders can be fully integrated into the sector (although probably not in large numbers). Clearly there is no easy fix regarding their participation and this will require substantial support from DAFF and acceptance from all recognised associations. Here, based on our own experiences in conducting this research, we would like to raise the question of how accessible the fishing industry really is to people, especially to those that had been marginalised formerly. As researchers, we experienced difficulties in understanding the data provided by DAFF and it was difficult to make contact with parties using details provided by MAST. For rights holders who have gained little knowledge of the industry since 2006, probably as a result of over-reliance on catching and processing agreements, it may be difficult for them to navigate through DAFF's structural and management environment. Working through government administrative systems can be challenging at the best of times, for various reasons. This might present difficulties for rights holders who do not understand government processes and who do not have support when dealing with government bureaucracy. Because of the frustrations that this can bring, it can be easier for rights holders to sell their quotas rather than try to learn the ropes of the industry and its protocols. It is for this reason that we argue for structural shifts in the management of this industry - in terms of who enters the industry as well as how accessible this entry is.

In continuing to make space for small-rights holders in the small-pelagics fishing industry, we argue that structures need to be put in place to ensure that those trying to make a living out of fishing are given the space to do so without having to sell their quotas. As the case studies and interviews suggest, there are still rights holders, especially in the category of HDI, that are not skilled or experienced in the practice of running a commercial fishing company (Hara and Raakjær 2009), which is one of the key factors for success in the sector. ${ }^{1919}$ Some of the small-rights holders have called

\footnotetext{
${ }^{18}$ The Policy for the Transfer of Commercial Fishing Rights (RSA 2009) prescribes how a right may be transferred. The Department requires a Transferee to be at least as transformed as the Transferor in order to promote transformation in the fishing sector

${ }^{19}$ One of the requirements for being granted a right is the capability to run a successful fishing business. DAFF therefore grants rights on the basis that rights holders have the skills or the potential to actively participate in the industry
} 
for training and mentoring programmes driven by government in order to empower and help them to become established in the industry and hence to ensure genuine transformation. Such programmes do not necessarily have to be run by DAFF. There are other government departments, such as DTI, as well as NGOs that have the mandate to undertake such programmes. In other instances, some of those who have fished all their lives have been excluded from the industry by the rights allocation process because they do not fit the category of HDI. In this context, the structure that we argue needs to be in place is a rights allocation process that retains skills and that allocates rights to those that are deserving, not only to enforce transformation but also to ensure that a best-skilled sector is achieved to the benefit of South African society. What the allocation process needs to be able to do in future, therefore, is identify and allocate rights to genuine fishers with interest in the industry - those willing to stay the course and build durable fishing businesses.

In reality, very few small-rights holders fish on an individual or private basis or are direct members of the recognised stakeholder associations. We have attempted to illustrate why this may be the case and have raised some of the issues and practices that result from this. For all stakeholders to be involved in the industry and in management of the sector, closer attention needs to be paid to the everyday realities of individual smallrights holders and the challenges that they face which debilitate their active participation in the governance of the industry.

Acknowledgements - This research was part of the Defragmenting Resource Management in Southern Africa (DARMA) project (AFS/2009/219017) funded by the European Union through the African Caribbean and Pacific (ACP) Science and Technology Programme (Europe Aid/127860/D/ACT/ACP). The contents of this article are the sole responsibility of the authors and do not reflect the views and position of the European Union. We thank all the stakeholders who agreed to be interviewed for the research and the reviewers that made the publication possible. 


\section{References}

Bavinck M, Chuenpagdee R, Diallo M, van der Heijden P, Kooiman J, Mahon R, Williams $\mathrm{S}$. 2005. Interactive fisheries governance: a guide to better practice. Delft: Eburon.

Butterworth DS. 2007. Why management procedures approach? Some positives and negatives. ICES Journal of Marine Science 64: 613-617.

DAFF (Department of Agriculture, Forestry and Fisheries). 2010. Draft terms of reference for management working groups (MWG). Unpublished report. DAFF, Cape Town.

DAFF (Department of Agriculture, Forestry and Fisheries). 2012a. 2009/10 Performance review of fishing right holders. Overall report/summary: limited commercial and full commercial rights holders. Unpublished report. DAFF, Cape Town.

DAFF (Department of Agriculture, Forestry and Fisheries). 2012b. Small pelagic approved initial anchovy TAC and final sardine TAC. Unpublished report. DAFF, Cape Town.

DEAT (Department of Environmental Affairs and Tourism). 2005a. General policy on the allocation and management of long term commercial fishing rights, 2005. Unpublished report. DEAT, Pretoria.

DEAT (Department of Environmental Affairs and Tourism). 2005b. Policy for the allocation and management of commercial fishing rights in the small pelagics (anchovy and sardine purse-seine) fishery: 2005. Unpublished report. DEAT, Pretoria.

DEAT (Department of Environmental Affairs and Tourism). 2007. Invitation to comment on the draft policy for transfer of commercial fishing rights. Government Gazette, South Africa 510(30574).

de Moor CL, Butterworth DS. 2008. OMP-o8. Unpublished DAFF scientific working group document MCM/2008/SWG-PEL/23. Department of Agriculture, Forestry and Fisheries, Cape Town.

Fairweather TP, Hara M, van der Lingen CD, Raakjær J, Shannon LJ, Louw GG, Degnbol P, Crawford RJM. 2006. A knowledge base for management of the capital-intensive fishery for small pelagic fish off South Africa. African Journal of Marine Science 28: 645-660.

FAO (Food and Agriculture Organization). 2003. The ecosystem approach to fisheries: issues, terminology, principles, institutional foundations, implementation and outlook. FAO Fisheries Technical Paper No. 443. Rome: FAO.

George Warman Publications. 2007. Fishing industry handbook: South Africa, Namibia and Mozambique (35th edn). Cape Town: George Warman Publications.

George Warman Publications. 2013. Fishing industry handbook: South Africa, Namibia and Mozambique (41st edn). Cape Town: George Warman Publications.

Gray T (ed.). 2005a. Participation in fisheries governance. Dordrecht: Springer.

Gray T. 2005b. Theorising about participatory fisheries governance. In: Gray T (ed.), Participation in fisheries governance. Dordrecht: Springer. pp 1-25.

Hara M. 2013. Efficacy of rights-based management of small pelagic fish within an ecosystems approach to fisheries in South Africa. African Journal of Marine Science 35: 315-322. 
Hara M, Raakjær J. 2009. Policy evolution in South African fisheries: the governance of the sector for small pelagics. Development Southern Africa 26: 649-662.

Hersoug B, Rånes SA. 1997. What is good for the fishermen is good for the nation: comanagement in the Norwegian fishing industry in the 1990s. Ocean and Coastal Management 35: 157-172.

Hutchings L, Augustyn CJ, Cockcroft A, van der Lingen C, Coetzee RW, Leslie RJ, Tarr R, Oosthuizen H, Lipiński MR, Roberts MR, Wilke C, Crawford R, Shannon LJ, Mayekiso M. 2009. Marine fisheries monitoring programmes in South Africa. South African Journal of Science 105: 182-192.

Isaacs M, Hara M, Raakjær J. 2007. Has reforming South African fisheries contributed to wealth redistribution and poverty alleviation? Ocean and Costal Management 50: 301-313.

Jentoft S. 1989. Fisheries co-management: delegating government responsibility to fishermen's organisations. Marine Policy 13: 137-154.

Jentoft S, McCay B. 1995. User participation in fisheries management: lessons drawn from international experiences. Marine Policy 19: 227-246.

Kooiman J, Bavinck M. 2005. The governing perspective. In: Kooiman J, Bavinck M, Jentoft S, Pullin R (eds), Fish for life: interactive governance for fisheries. Amsterdam: Amsterdam University Press. pp 11-24.

Kooiman J, Bavinck M, Jentoft S, Pullin R (eds). 2005. Fish for life: interactive governance for fisheries. Amsterdam: Amsterdam University Press.

Michels R. 1915. Political parties: a sociological study of the oligarchical tendencies of modern democracy. Translated into English by E Paul and C Paul. 2001. New York: Batoche Books, Kitchener.

Mikalsen KH. 1998. Regulation and representation: institutional challenges in fisheries management. In: Gray TS (ed.), The politics of fishing. Basingstoke: Macmillan Publishers Ltd. pp 100-115.

Mikalsen K, Jentoft S, Hoel AH. 1996. User-group participation in Norwegian fisheries management. In: Meyers RM, Zhang C, Windsor ML, McCay B, Hushak L, Muth R (eds), Fisheries utilization and policy. Theme 2. Proceedings of the World Fisheries Congress. New Delhi: Oxford \& IBH Publishing. pp 287-303.

Nyikahadzoi K, Hara M, Raakjær J. 2010. Transforming ownership and governance: lessons from capital intensive pelagic fisheries in South Africa and Zimbabwe. International Journal of the Commons 4: 663-682.

Paterson B, Isaacs M, Hara M, Jarre A, Moloney CL. 2010. Achieving transdisciplinary co-operation for EAF: a South African case study. Marine Policy 34: 782-794.

Paterson B, Petersen S. 2010. EAF implementation in southern Africa: lessons learnt. Marine Policy 34: 276-292.

Petersen S, Paterson B, Basson J, Moroff N, Roux J-P, Augustyn J, D’Almeida G (eds). 2010. Tracking the implementation of an ecosystem approach to fisheries in southern Africa. WWF South Africa Report Series: 2010/Marine/o01. Cape Town.

Raakjær Nielsen J, Hara MM. 2006. Transformation of South African industrial fisheries. Marine Policy 30: 43-50.

RSA (Republic of South Africa). 1996. Constitution of the Republic of South Africa (Act No. 108 of 1996). Government Gazette, South Africa 378(17678).

RSA (Republic of South Africa). 1998a. National Environmental Management Act (Act No. 107 of 1998). Government Gazette, South Africa 401(19518). 
RSA (Republic of South Africa). 1998b. Marine Living Resources Act (Act No. 18 of 1998). Government Gazette, South Africa 395(18930).

RSA (Republic of South Africa). 2000. Promotion of Access to Information Act (Act No. 2 of 2000). Government Gazette, South Africa 416(20852).

RSA (Republic of South Africa). 2003. National Small Business Amendment Act (Act No. 26 of 2003). Government Gazette, South Africa No. 24628, 27 March 2003.

RSA (Republic of South Africa). 2004. NEMA: Air Quality Act (Act No. 39 of 2004). Government Gazette, South Africa 476(27318).

RSA (Republic of South Africa). 2009. Policy for the transfer of commercial fishing rights. Government Gazette, South Africa No. 32449, 31 July 2009.

Sen S, Raakjær Nielsen J. 1996. Fisheries co-management: a comparative analysis. Marine Policy 20: 405-418.

Shannon LJ, Cochrane KL, Moloney CL, Fréon P. 2004. Ecosystem approaches to fisheries in the southern Benguela: a workshop overview. In: Shannon LJ, Cochrane KL, Pillar

SC (eds), Ecosystem approaches to fisheries in the southern Benguela. African Journal of Marine Science 26: 1-8.

Shannon LJ, Jarre AC, Petersen SL. 2010. Developing a science base for implementation of the ecosystems approach to fisheries in South Africa. Progress in Oceanography 87: 289-303.

Swyngedouw E. 2005. Governance innovation and the citizen: the Janus face of governance-beyond-the-state. Urban Studies 42: 1991-2006.

Symes D. 1997. Co-governance in marine and coastal fisheries. In: Report on seminar on cooperation in management of the North Sea and Wadden Sea fisheries, Groningen, 9-10 January 1997. Ministry of Agriculture, Nature Management and Fisheries, The Hague. pp 1-12.

Symes D. 2006. Fisheries governance: a coming of age for fisheries social science? Fisheries Research 81: 113-117.

van der Lingen CD, Coetzee JC, Hutchings LF. 2011. Causes and effects of changes in the distribution of anchovy and sardine in shelf waters off South Africa. In: Zietsman L (ed.), Observations on environmental change in South Africa. Stellenbosch: SUN MeDIA. pp 252-257.

Wilson DG, Raakjaer Nielsen J, Degnbol P (eds). 2003. The fisheries co-management experience: accomplishments, challenges and prospects. Dordrecht: Kluwer. 